\title{
Establishment of disaster debris management based on quantitative estimation using natural hazard maps
}

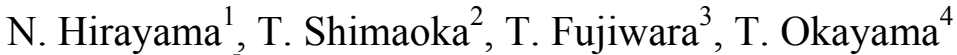 \\ \& Y. Kawata ${ }^{5}$ \\ ${ }^{I}$ Department of Environmental Engineering, Kyoto University, Japan \\ ${ }^{2}$ Department of Urban and Environmental Engineering, \\ Kyushu University, Japan \\ ${ }^{3}$ Department of Waste Management, Okayama University, Japan \\ ${ }^{4}$ Meijo University, Japan \\ ${ }^{5}$ Graduate School of Safety Science, Kansai University, Japan
}

\begin{abstract}
In this study, an estimation procedure was established to assess the amount of debris resulting from earthquake and flood disasters. Per unit generation of earthquake disaster debris was examined on the basis of observed debris discharge from the 1995 Great Hanshin Awaji Earthquake and the 2004 Niigata Chuetsu Earthquake. In addition, the per unit generation of disaster debris from flood damage above floor level was estimated at $4.6 \mathrm{t} /$ household. It was shown that this procedure would allow the amount of debris to be estimated in order that disaster management and operation systems could be established for not only emergency response in the aftermath, but also pre-disaster planning. In a case study, the amount of disaster debris from earthquake and catastrophic flood disasters in the Tokyo Metropolitan Area was estimated according to hazard maps. It is concluded that it is important, from the viewpoint of the security of sanitary systems in the damaged district, that disaster debris management systems including wide-ranging cooperative measures should be established.
\end{abstract}

Keywords: disaster debris, estimation procedure, natural hazard zone maps, per unit generation, extent of housing damage. 


\section{Introduction}

In Japan, natural disasters frequently affect the life of residents as well as their social and economic activities. The Great Hanshin-Awaji Earthquake in 1995, the 2004 Mid Niigata Prefecture Earthquake, the Not Hanto Earthquake in 2007, the Niigata-ken Chuetsu-oki Earthquake in 2007, the 2004 Flood Disaster in Hyogo Prefecture as a result typhoon No.23, and the Miyazaki Flood Disaster caused by typhoon No.14 in 2005 are some examples. The country has also experienced some catastrophic disasters: the Tokai Earthquake, the Tonankai and Nankai Earthquake, and an earthquake and a catastrophic flood in the Tokyo Metropolitan Area.

After natural disasters such as earthquakes and floods, enormous quantities of disaster debris would be discharged from collapsed houses and buildings and damaged household goods. Therefore, environment and waste management authorities should establish effective and appropriate disaster management systems for the emergency removal of debris from urban districts and their disposal.

Emergency debris treatment after natural disasters has been widely researched since the Great Hanshin-Awaji Earthquake in 1995. The waste processing technology introduced after the Hanshin-Awaji Earthquake was examined [1]. Field studies on per unit generation of demolition waste and change of municipal solid waste composition were carried out in Kobe and Hanshin areas [2]. Per unit generation of waste was determined by weight and volume. Solid waste management practices in the initial stage of revival after the Great HanshinAwaji Earthquake and other huge natural disasters were examined and debris treatment problems identified [3].

Emergency debris operations were examined from the standpoint of disaster response [4]. After the Great Hanshin-Awaji Earthquake of 1995, Earthquake Disaster Debris Management Guidelines were published by the Ministry of Welfare [5]. In addition, after the 2004 flood disasters, Flood Disaster Waste Management Guidelines were published by the Ministry of the Environment [6]. Considering the whole disaster management cycle, emergency debris management after disasters is an area that has received little research interest.

To carry out emergency debris operation as soon as possible, as well as appropriately, it is important to establish a strategic plan for debris operation and emergency debris management. For strategic planning of emergency debris operations, including establishment of cooperative measures, the quantity of disaster debris needs to be estimated at not only the emergency response phase, after the disaster, but also the pre-disaster stage. The purpose of this study is to develop an estimation procedure for disaster debris discharge based on natural hazard maps.

\section{Methodology}

\subsection{Estimation procedure for disaster debris discharge}

The Great Hanshin-Awaji Earthquake of 1995 produced a strong impact on buildings and generated approximately 20 million $t$ of debris [7] -14.5 million $t$ 
from collapsed private houses and buildings and 5.5 million t from public works and collapsed public buildings and structures. After the earthquake, it was difficult to estimate the quantity of debris, and the estimate was revised appropriately, following an increase in the number of demolished buildings.

In 2000, a flood disaster struck Tokai region as a result of heavy rainfall. The levees of Shinkawa River burst and the Shonai River overflowed, inundating the Tokai region, mainly the western part of Nagoya. The flood damaged more than 70,000 houses, and resulted in $81,400 \mathrm{t}$ of debris [8]. In 2004, ten typhoons struck Honshu, and many cities were severely affected. More than $70 \%$ of downtown Toyonaka was inundated for two days after typhoon No.23 hit Hyogo Prefecture. An enormous amount of debris was generated in the stricken cities.

In Japan, the Disaster Countermeasures Basic Act assigns responsibility for reporting damage, including the extent of damage to buildings, and progress of emergency operations to higher levels of the administration [9]. After a disaster, reports of the damage, including the number of houses affected, should be announced by the Fire and Disaster Management Agency (FDMA) of the Ministry of Internal Affairs and Communications, Government of Japan. The quantity of disaster debris is estimated by eqn (1) on the basis of per unit generation of debris, including rubble from damaged housing structures.

$$
W_{D}=\sum C_{i} N_{i}
$$

The quantity of disaster debris is designated by WD. Ci represents per unit generation of debris, including rubble from damaged housing structure, and the subscript $\mathrm{i}$ refers to the classification of building damage. The number of damaged buildings is designated by $\mathrm{Ni}$.

To estimate the quantity of disaster debris based on the damage report, we need to assume per unit generation, including that from building damage. In Japan, local governments have developed natural hazard maps with the assistance of the Ministry of Land, Infrastructure, Transport and Tourism. The number of damaged houses can be estimated on the basis of the fragility function of buildings from census data such as population and number of houses and households and damage data on natural hazard maps, such as seismic intensity, inundation depth, and inundation areas. Thus, the quantity of disaster debris would be estimated, as shown in Figure 1, from per unit generation of debris multiplied by the number of houses damaged, calculated from the damage data on the hazard map. The scale and resolution of this estimation would depend on those of the census data or the natural hazard map. Therefore, this procedure would be adapted to different data scales and resolutions of grid cells in the Geographic Information System (GIS).

\subsection{Simulation studies of per unit generation of disaster debris}

\subsubsection{Earthquake disaster debris}

Since the Great Hanshin-Awaji Earthquake, several studies have been made on the determination of per unit generation of earthquake disaster debris. Field 


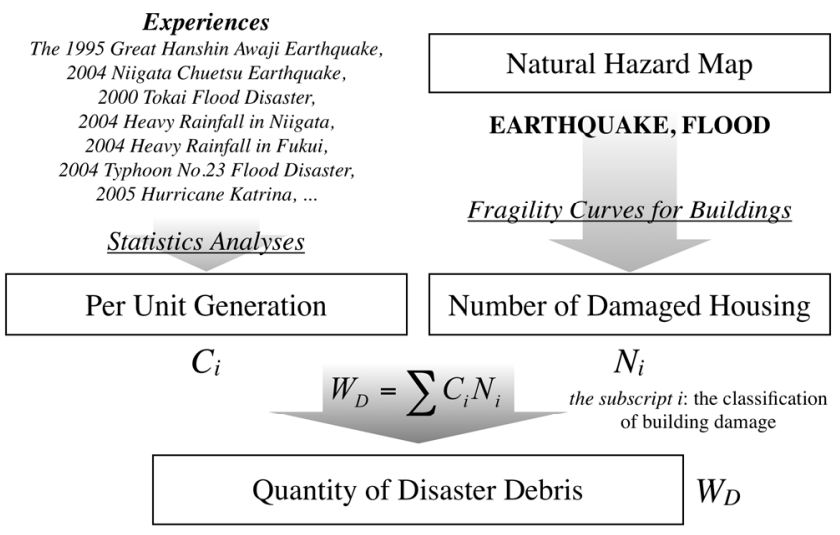

Scalability: Grid cells in Geographical information system (GIS), Administrative wards (local governments), Nationwide, Disasters

Figure 1: Estimation procedure for quantity of disaster debris using natural hazard maps.

studies on per unit generation of demolition debris and composition change of municipal solid waste have been conducted, and per unit generation of demolition debris from wooden houses was estimated at $0.40 \mathrm{t} / \mathrm{m}^{2}$ to $0.61 \mathrm{t} / \mathrm{m}^{2}$ [2]. Watanabe reported the estimation procedure for disaster debris from the 1995 Great Hanshin-Awaji Earthquake and determined per unit generation by volume as $96.0 \mathrm{~m}^{3} /$ house [9]. The Mid Niigata Prefecture Earthquake of 2004 and the Niigataken Chuetsu-oki Earthquake of 2007 hit the Niigata Chuetsu district and caused enormous discharge of disaster debris. In the Mid Niigata Prefecture Earthquake, per unit generation of disaster debris caused by demolition and construction of housing was reported as $57 \mathrm{t} /$ house to $85 \mathrm{t} /$ house [10].

In the Great Hanshin Awaji Earthquake of 1995, complete collapses of housing units numbered 104,906, and moderate collapses 144,274 [11]. The quantity of disaster debris from collapsed private houses and buildings was estimated at 14.5 million $\mathrm{t}$ [7]. Thus, on the assumption that moderate collapse would generate half as much disaster debris as complete collapse, per unit generation of disaster debris from the Hanshin-Awaji Earthquake was estimated at 81.9 t/house. Considering that the objective of this procedure is to estimate total debris discharge in the aftermath of the earthquake disaster from not only private housing but also public buildings and public works, per unit generation of earthquake disaster debris was estimated at $113 \mathrm{t} /$ house. On the other hand, per unit generation of earthquake disaster debris was estimated at 61.9 t/household based on the data of damaged households in the 1995 Earthquake, in which 186,175 complete collapses and 274,182 moderate collapses were reported. 


\subsubsection{Flood disaster debris}

Researchers have established an estimation procedure for disaster debris caused by floods for emergency response operations and estimated per unit generation of disaster debris, including rubble from building collapse [12]. In order to estimate the quantity of disaster debris based on the FDMA damage report, we need to consider per unit generation from building damage also. A questionnaire-based survey on disaster debris generation was carried out among local governments in regions affected by flood disasters from 1999 to 2005 where the Disaster Relief Act was applied. Multiple regression analysis was performed to estimate per unit generation of flood disaster debris. The estimation was estimated at $4.6 \mathrm{t} /$ household from flood damage above the floor level and at $0.62 \mathrm{t} /$ household from inundation damage below the floor level.

Hurricane Katrina of 2005 caused an enormous volume of debris, estimated at 51.2 million cubic meters, in the State of Louisiana [13]. Figure 2 shows the quantity of disaster debris caused by Hurricane Katrina and other natural disasters in Japan after 1995 [14]. The figure indicates that Hurricane Katrina produced 1.34 times the debris caused by the Great Hanshin-Awaji Earthquake. Among all natural disasters, only earthquakes would generate more than a hundred thousand tons of debris. In the Hurricane Katrina disaster, each home typically generated about 300 cubic yards of construction and demolition debris presumed that a catastrophic flood would cause approximately the same quantity of debris as earthquakes.

\subsubsection{Per unit generation of disaster debris}

Estimations of per unit generation of disaster debris are shown in Table 1. The assumptions in Case 1 to Case 3 are based on per unit generation for earthquake disasters. The estimation in Case 1 is based on the number of households. Per unit generation in Case 2 is based on the number of houses damaged. In Case 3, per unit generation of earthquake disaster debris is used to estimate the total quantity of debris discharged by both private housing and public buildings and works damaged.

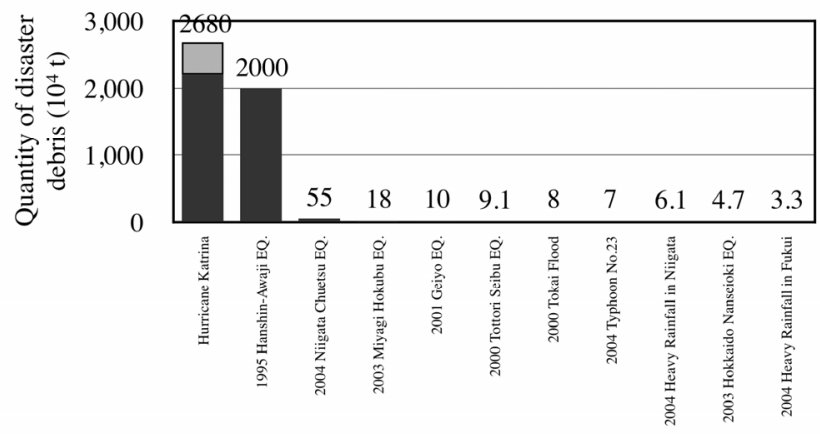

Figure 2: Quantity of disaster debris caused by Hurricane Katrina and other natural disasters in Japan after 1995. 
Table 1: $\quad$ Estimations of per unit generation of disaster debris.

\begin{tabular}{cccccc}
\hline \multirow{2}{*}{ Disaster } & & \multicolumn{4}{c}{ Disaster debris discharge (t/household) } \\
\cline { 3 - 6 } & Cases & $\begin{array}{c}\text { Complete } \\
\text { collapse }\end{array}$ & $\begin{array}{c}\text { Moderate } \\
\text { collapse }\end{array}$ & $\begin{array}{c}\text { Floor level } \\
\text { inundation }\end{array}$ & $\begin{array}{c}\text { Inundation } \\
\text { damage } \\
\text { below the } \\
\text { floor level }\end{array}$ \\
\hline \multirow{3}{*}{ Earthquake } & Case 1 & 60.0 & 30.0 & N/D & N/D \\
\cline { 2 - 6 } & Case 2 & 85.0 & 42.5 & N/D & N/D \\
\cline { 2 - 6 } Flood & Case 3 & 113.0 & 56.5 & N/D & N/D \\
\cline { 2 - 6 } & Case 4 & 60.0 & 30.0 & 4.6 & 0.62 \\
\hline
\end{tabular}

Cases 4 and 5 illustrate per unit generation of flood disaster debris. Per unit generation of the flood disaster debris is estimated by statistical analysis in Case 4. According to Case 5, houses damaged by above-flood-level inundation and completely damaged housing generate the same amount of debris in catastrophic flood disasters.

\subsection{Computation of disaster debris discharge}

As mentioned above, the quantity of disaster debris can be estimated in both per and post-disaster stages on the basis of per unit generation (see Table 1). Estimation in the aftermath based on the procedure in this study would require a report of disaster damages, including the number of damaged housing. On the other hand, estimation of housing damage in the pre-disaster stage would be based on hazard maps. In this section, we describe the procedure to estimate the number of damaged housed from damage data in the hazard maps.

Generally, earthquake disaster hazard maps display expected seismic intensities. In this study, the fragility function of wooden housing, shown in Figure 3, is used to calculate the number of damaged houses according to seismic intensities based on the Japanese seismic scale.

Fragility curves have been developed for buildings in relation to inundation depth of overflow [15]. They indicate that inundation depths of more than $2 \mathrm{~m}$

Using correlations between natural hazards and housing damage, we can estimate the number of damaged houses from the information in hazard maps. Consequently, these computation procedures could allow the quantity of debris to be estimated for establishment disaster management and operation systems for not only emergency response in the aftermath but also pre-disaster planning. 


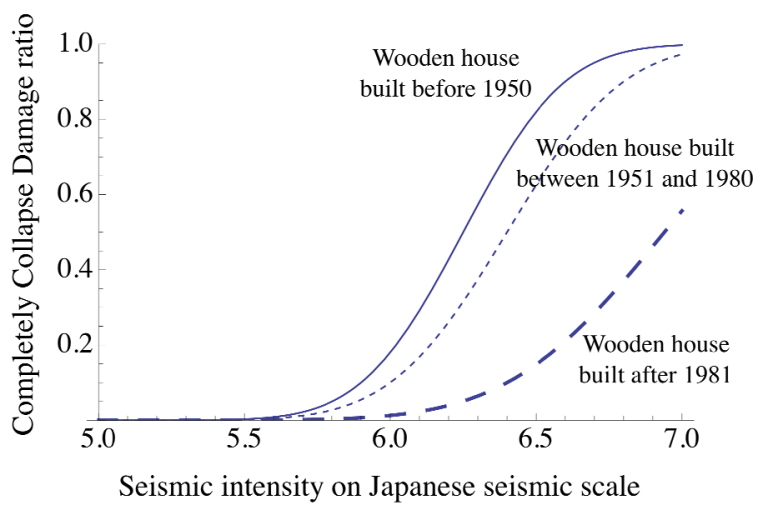

Figure 3: The fragility function of wooden housing.

\section{Estimation of disaster debris discharge}

In this part, the comprehensive estimation procedure for debris discharge caused by earthquake and catastrophic flood disasters in the Tokyo Metropolitan Area is described.

\subsection{Earthquake disasters in Tokyo metropolitan area}

The Central Disaster Prevention Council estimates damage from scenario earthquakes. First, from the household distribution of the Tokyo Metropolitan Area and the earthquake ground motion, the number of damaged houses was calculated based on the fragility function mentioned previously. According to the damage estimates, 241,873 houses suffered complete collapse and 1,388,147 houses sustained moderate collapse.

Then, using per unit generation of earthquake disaster debris in Case 1, we calculated the discharge of debris from the earthquake as shown in Figure 4. In Case 1, the quantity of earthquake debris was estimated at 56.2 million $t$ based on per unit generation of debris in the 1995 Hanshin-Awaji Earthquake-60 t/household from complete collapse. Table 2 summarizes the estimation results on the amount of earthquake debris in each case.

The Central Disaster Prevention Council evaluated the amount of debris from earthquake disasters in the Tokyo Metropolitan Area on the basis of the spatial per unit generation of earthquake debris [17]. According to their method, the debris from the Tokyo Metropolitan Area earthquake was estimated at 96 million $t$. In this result, it is believed that the wind would have to blow at a speed of $15 \mathrm{~m}$ per second. This shows that the computation results of this study should be less than those of the council. We strongly believe that both postdisaster and pre-disaster estimations would be easier to compute according to the procedure adopted in this study. Therefore, we assume that this procedure would be accepted for earthquake disaster debris estimations. 
Table 2: $\quad$ Summary of the estimation results on the amount of earthquake debris in each case.

\begin{tabular}{cccc}
\hline & $\begin{array}{c}\text { Complete } \\
\text { Collapse } \\
\text { (household) }\end{array}$ & $\begin{array}{c}\text { Moderate } \\
\text { Collapse } \\
\text { (household) }\end{array}$ & $\begin{array}{c}\text { Earthquake } \\
\text { Disaster Debris } \\
\text { Case 1 }\end{array}$ \\
\hline Case 2 & & & $56,156,790$ \\
\cline { 1 - 1 } \cline { 4 - 4 } Case 3 & 241,873 & $1,388,147$ & $79,555,453$ \\
\cline { 1 - 1 } $\begin{array}{c}\text { The central disaster } \\
\text { prevention council }\end{array}$ & 850,000 houses & 21,000 houses & $96,000,000$ \\
\hline
\end{tabular}

\begin{tabular}{l} 
Case 1 condition; \\
Complete Collapse: $60.0 \mathrm{t}$ \\
Moderate Collapse: $30.0 \mathrm{t}$ \\
\\
\\
\hline $0 \quad 50000$ 100000 $56,156,790 \mathrm{t}$ \\
Earthquake disaster debris $(\mathrm{t})$
\end{tabular}

Figure 4: Estimation results of the discharge of debris from earthquake disasters in the Tokyo metropolitan area using per unit generation of earthquake disaster debris.

\subsection{Catastrophic flood disasters of Tokyo metropolitan area}

The Central Disaster Prevention Council has investigated countermeasures against catastrophic flood disasters in the Tokyo Metropolitan Area [18], and estimated the damage from flood disasters in the area. The inundation depth of the Tone River flood disaster has been calculated. Figure 5 illustrates the flood assumption zone map of Tone River in the case of a catastrophic flood disaster in the Toyo Metropolitan Area. Thus, the number of damaged houses has been calculated on the basis of the correlation between inundation depth and housing damage, as mentioned above. According to estimations of damage from flood disasters, 631,547 houses would suffer damage beyond floor level inundation. It can be shown that as many as 247,491 houses in Adachi, Edogawa, and Katsushika wards on the coast of Tokyo Bay would be damaged. A period of 


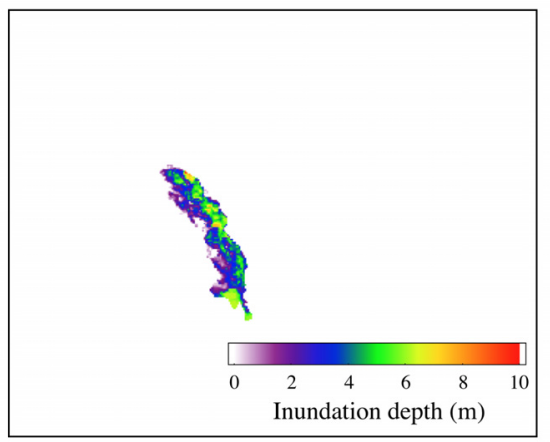

Figure 5: The flood assumption zone map of the Tone river in the case of a catastrophic flood disaster in the Tokyo metropolitan area.

inundation in these wards of more than three weeks was estimated. It may be assumed that damage to housing in the Tokyo Bay coast could be even more.

First, the amount of debris from a Tone River flood disaster in the Tokyo Metropolitan Area has been calculated based on housing damage and per unit generation in Case 4. The total amount of flood disaster debris has been estimated at 7.47 million $t$. As mentioned above, it is presumed that most of the inundation area in a Tone River flood disaster would suffer housing damage due to long-period inundation-more than two weeks. From the amount of disaster debris caused by Hurricane Katrina, it seems reasonable to suppose that longperiod inundation would generate debris from damaged houses. If it is assumed that housing damage from above-floor-level inundation generates the same quantity of flood disaster debris as earthquake disasters, per unit generation of flood disaster debris from long-period inundation could be as much as 60 $\mathrm{t} /$ household on the basis of Case 5. In Case 5, the amount of disaster debris was calculated from per unit generation, considering a long period of inundation. The total quantity of disaster debris was estimated at 42.4 million t. Estimation results of debris from catastrophic flood disasters in the Tokyo Metropolitan Area are shown in Figure 6.

\subsection{Results and discussion}

In this paper, an estimation procedure for the quantity of debris caused by earthquakes and flood disasters was developed. Per unit generation of disaster debris caused by earthquakes and floods was examined. According to this estimation procedure, the amount of disaster debris from simulated disasters such as the earthquake and catastrophic flood in the Tokyo Metropolitan Area was calculated on the basis of hazard zone maps. It was shown that this procedure would make it possible to estimate debris discharge for establishment of disaster management systems not only as emergency response measures in the aftermath but also for pre-disaster planning. 


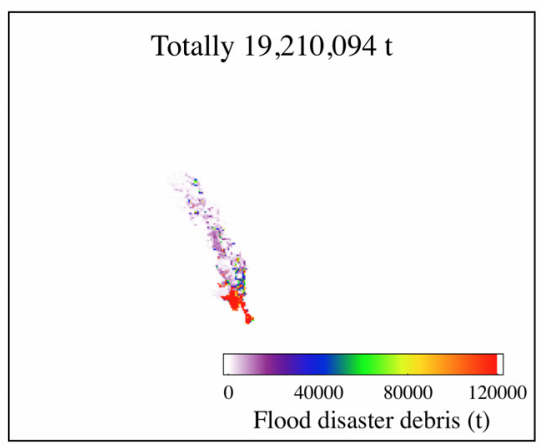

Figure 6: Estimation results of debris from catastrophic flood disasters in the Tokyo metropolitan area.

Let us now consider the quantity of disaster debris from the viewpoint of the emergency response. From these estimation results, we may conclude that earthquake and catastrophic flood disasters in the Tokyo Metropolitan Area are not just regional crises that local governments can deal with but are enormous calamities that need the national government's intervention. Further, these catastrophic disasters would need a high level of response competence than public authorities can offer. Furthermore, it is important, from the viewpoint of the security of sanitary systems in the damaged district, that wide-ranging cooperative measures should be established for emergency removal and treatment in pre-disaster stage.

\section{Conclusion}

An estimation procedure was established to quantity disaster debris based on per unit generation. In addition, the working of estimation procedures to evaluate the discharge of disaster debris from earthquakes as well as catastrophic flood disasters is analyzed. We achieved some important results from the study:

1) A procedure to estimate the quantity of disaster debris caused by earthquakes and flood disasters on basis of hazard zone maps was established. Per unit generation of disaster debris, depending on the extent of housing damage, was estimated. It is shown that this procedure will allow both postdisaster and pre-disaster estimations.

2) It was pointed out that a catastrophic flood disaster would cause approximately the same quantity of debris as earthquake disasters.

3) The quantities of debris caused by earthquake and catastrophic flood disasters in the Tokyo Metropolitan Area have been calculated according to damage information on natural hazard maps.

4) It is concluded that natural disasters in Japan are crises for not only local governments but also the national government. Furthermore, we have shown that it is important, from the viewpoint of the security of sanitary systems in the damaged district, that cooperative measures should be established for emergency debris removal and treatment as soon as possible. 


\section{Acknowledgements}

We thank the Cabinet Office, Government of Japan for providing information on earthquakes and flood disasters in the Tokyo Metropolitan Area. This work was supported by Grants-in-Aid for Scientific Research from The Ministry of Environment and Kyoto University Global COE Program "Global Center for Education and Research on Human Security Engineering for Asian Megacities"

\section{References}

[1] T. Nakamichi \& M. Inoue, Treatment Systems \& Technologies for Disaster Waste, Waste Management Research, 6(5), pp. 394-401, 1995.

[2] H. Takatsuki, S. Sakai, \& S. Mizutani, Disaster and Waste Problems -Per Unit Generation of the Disaster Waste and the Composition Changes of Municipal Solid Waste-, Waste Management Research, 6(5), pp. 351-359, 1995.

[3] T. Shimaoka, An Investigation on Solid Waste Generation by Natural Disasters and Disposal Measures, Waste Management Research, 6(5), pp. 360-372, 1995.

[4] T. Harukaze, M. Kito, \& N. Tsukidani, (1997); Separation, Recycle and Disposal of Waste Derived from Great Hanshin-Awaji Earthquake, Proc. of the $19^{\text {th }}$ Symposium of Association of Environmental and Sanitary Engineering Research, 11(3), pp. 67-72, 1997.

[5] Ministry of Welfare, Earthquake Disaster Debris Management Guidelines, 1998.

[6] Ministry of the Environment Government of Japan, Flood Disaster Waste Management Guidelines, 2005.

[7] Hyogo Prefecture, Earthquake Disaster Debris Operation, Documentation of Recovery and Reconstruction after the Great Hanshin-Awaji Earthquake, 1, pp. 215-225, 1997.

[8] Ministry of Land, Infrastructure and Transport, Assessment of Disaster Damages in 2000, p. 41, 2001.

[9] N. Watanabe, Characteristic of Generation of Disaster Debris on the Great Hanshin Awaji Earthquake, Proc. of Earthquake Waste Symposium 1996, pp. 93-110, 1996.

[10] Kanto District Office, Ministry of the Environment Government of Japan, Report of Effective Reuse and Recycle of Demolition and Construction Debris after Large-scale Disaster and Appropriate Disaster Debris Treatment, 2006.

[11] Fire and Disaster Management Agency of the Ministry of Internal Affairs and Communications of Japan, Disaster Damage Report on the 1995 Great Hanshin Awaji Earthquake (final), 2006.

[12] N. Hirayama \& Y. Kawata, Estimation Procedure for Quantity of Disaster Waste from the Viewpoint of Emergency Responses of Public Authorities at Flood Disaster, Selected Papers Environmental Systems Research, 33, pp. 29-36, 2005. 
178 Waste Management and the Environment V

[13] Disaster Reduction and Human Renovation Institute, Flood Disaster Debris Management in 2005 Hurricane Katrina Disaster (Chapter 7), A Study on Management of Emergency Response by Local Governments following 2005 Hurricane Katrina Disaster, DRI Technical Report Series, 16, pp. 55-62, 2006.

[14] N. Hirayama \& Y. Kawata, Emergency Debris Management Including Wide Area Cooperative Measures on the Super Huge Disasters, Proc. of the Fifth Asian-Pacific Landfill Symposium, CD-ROM, 2008.

[15] S. Suzuki, S. Koshimura, K. Harada, M. Okamoto, K. Fukutome, M. Suga, \& Y. Kawata, Development of Fragility Function for Wooden House Obtained from the Field Investigation of Flood Disaster due to July 13, 2004 Niigata Heavy Rainfall, Jour of Hydroscience and Hydraulic Eng., 49, pp. 439-444, 2005.

[16] Ministry of Land, Infrastructure and Transport, Instruction Manual for River Management and Economic Investigation, 2005.

[17] Central Disaster Prevention Council, Cabinet Office, Government of Japan, Estimation of Damage in Earthquakes in the Tokyo Metropolitan Area, 2004.

[18] Central Disaster Prevention Council, Cabinet Office, Government of Japan, Estimation of Damage in the Wide Area and Catastrophic Floods in the Tokyo Metropolitan Area, 2008. 